Bullen, J. J., and Rogers, H. J. (1969). Nature, 224, 380.

Bullen, J. J., Rogers, H. J., and Lewin, J. E. (1971). Immunology, 20, 391. Bullen, J. J., Wilson, A. B., and Cordiner, K. (1961). Fournal of Pathology and Bacteriology, 82, 383.

Bullen, J. J., Wilson, A. B., Cushnie, G. H., and Rogers, H. J. (1968). Immunology, 14, 889.

Collins, P. F., Diehl, H., and Smith, G. F. (1959). Analytical Chemistry, 31, 1862.

de Man, J. C., Rogosa, M., and Sharpe, M. E. (1960). fournal of Applied Bacteriology, 23, 130.

Fletcher, J., and Goldstein, E. (1970). British fournal of Experimental Pathology, 51, 280.

Griffiths, E. (1971a). Nature New Biology, 232, 89.

Griffiths, E. (1971b). European fournal of Biochemistry, 23, 69.

Henderson, S. G. (1942). American fournal of Roentgenology, Radium

Therapy, and Nuclear Medicine, 48, 302 .
Hewitt, L. F. (1950). In Oxidation-Reduction Potentials in Bacteriology and Biochemistry, 6th edn. Edinburgh, Livingstone.

Hirsch, A., and Grinsted, E. (1954). Fournal of Dairy Research, 21, 101.

Ingram, P. L., and Lovell, R. (1960). Veterinary Record, 72, 1183.

Kohler, E. M. (1967). Canadian fournal of Comparative Medicine and Veterinary Science, 31, 277. Laskowski, M., and Laskowski, M. (1951). fournal of Biological Chemistry,
190, 563.

Levi, D. (1941). British Medical fournal, 1, 963.

Mason, S. (1962). Archives of Diseases in Childhood, 37, 387.

Masson, P. L., and Heremans, J. F. (1966). Protides of Biological Fluids,

14, 115.
Masson, P. L., and Heremans, J. F. (1971). Comparative Biochemistry and Physiology, 39B, 119.

Masson, P. L., Heremans, J. F., and Schonne, E. (1969). fournal of Experimental Medicine, 130,643 .

Melching, L., and Vas, S. I. (1971). Infection and Immunity, 3, 107.

Paterson, J. S. (1969). IAT Manual of Laboratory Animal Practice and Techniques, 2nd edn., chap. 25, p. 424, London, Crosby Lockwood.

Rogers, H. J., Bullen, J. J., and Cushnie, G. H. (1970). Immunology, 19, 521.

Ross, C. A. C., and Dawes, E. A. (1954). Lancet, 1, 994.

Smith, H. W. (1962), Fournal of Pathology and Bacteriology, 84, 147.

Smith, J. (1955). Aetiology of Epidemic Infantile Gastro-Enteritis. Edinburgh, Royal College of Physicians.

Taylor, J. (1970). Proceedings of the Royal Society of Medicine, 63, 1297.

Thomson, S., Watkins, A. G., and Gray, O. P. (1956). Archives of Disease in Childhood, 31, 340.

\title{
Precipitins to Dietary Proteins in Serum and Upper Intestinal Secretions of Coeliac Children
}

British Medical fournal, 1972, 1, 75-77

\section{Summary}

We have used precipitin tests to detect antibodies to 10 dietary proteins in the serum (71 cases) and intestinal secretions (51 cases) of a group of children. Thirty-three of the patients had untreated coeliac disease. Our aims were to find out if, in coeliac patients, there was intestinal secretion of antibodies to wheat proteins only or if, as in coeliac serum, antibodies to many food proteins were present; and to confirm that secretion of antibodies to wheat or gluten was specific for coeliac disease.

Precipitins to one or more dietary antigens were detected in the intestinal secretions of 26 out of 30 coeliacs and of 11 out of 21 children who did not have coeliac disease. Most of the positive reactions were with the antigens wheat flour, gluten, oatmeal, and egg. Though precipitins to wheat flour or gluten were present in the intestinal secretions of 22 out of 30 coeliacs this was not specific for coeliac disease for these precipitins were also present in 8 out of 21 non-coeliac children.

Serum precipitins were detected in 27 out of 33 coeliacs (to the antigens wheat flour, gluten, oatmeal, rice flour, milk, bovine calf serum, sheep serum, and egg) and in 5 out of 33 non-coeliacs (mainly to milk and calf serum, but two infants aged 3 and 5 months had precipitins to several antigens).

\section{Introduction}

Though wheat gluten intolerance is a constant feature of coeliac disease there is still dispute about whether the primary defect is in the digestion and absorption of gluten or a hyper-

University Department of Bacteriology and Immunology, Western Infirmary, Glasgow W.1

ANNE FERGUSON, B.SC., M.R.C.P., Lecturer

Department of Child Health, University of Glasgow, Glasgow C.3 F. CARSWELL, PH.D., M.R.C.P., Lecturer reactivity of the lymphoid system with an abnormal immune response to gluten (Booth, 1970a; Rubin et al., 1970).

The first clinical studies of antijodies to dietary proteins showed that many coeliac patients had serum antibodies to wheat or gluten extracts (Taylor et al., 1961; Heiner et al., 1962). This became less significant when more extensive work showed serum antibodies to other dietary antigens-for example, milk, oats, sheep, bovine, and egg proteins (Taylor et al., 1961 ; Heiner et al., 1962; Alarcon-Segovia et al., 1964; Kenrick and Walker-Smith, 1970; Rossipal, 1970)-foods to which these coeliac patients were not clinically intolerant. Most authors now consider that the presence of these serum antibodies is related to increased permeability to macromolecules of the inflamed smallintestinal mucosa (Alarcon-Segovia et al., 1964; Booth, 1970b; Kenrick and Walker-Smith, 1970).

Antibodies to a peptic-tryptic digest of gluten have been detected in the intestinal secretions and stools of coeliac patients, but not in control subjects (Herskovic et al., 1968; Katz et al., 1968). This was held to suggest that intestinal secretion of antibodies to gluten is specific for coeliac disease. Unfortunately, in these investigations of coeliac and control patients no tests were performed which would detect antibodies to dietary proteins other than wheat.

We have studied a group of children (including 33 coeliacs) further to investigate secretion of antibodies to dietary proteins. Our main purpose was to find out if, in coeliacs, there was intestinal secretion of antibodies to wheat proteins only or if, as in their serum, antibodies to many food proteins were present. We also hoped to confirm that secretion of antibodies to wheat or gluten was specific for coeliac disease.

\section{Patients and Methods}

The 71 children studied were all inpatients in the Royal Hospital for Sick Children, Glasgow; most were undergoing investigation for suspected gastrointestinal diseases; all were taking a normal gluten- and milk-containing diet. Subsequently, in 33 cases a diagnosis of coeliac disease was made on the basis of (1) upper intestinal histology of subtotal villous atrophy or severe partial villous atrophy, and (2) clinical improvement on a gluten-free diet. One of these coeliac patients also had IgA 
deficiency. Table I summarizes the age and sex distribution of coeliac and non-coeliac children, and the final diagnoses of the 38 non-coeliacs are listed in Table II.

TABLE I-Age and Sex Distribution of Patients Studied

\begin{tabular}{|c|c|c|c|c|c|c|c|}
\hline & \multirow{3}{*}{\multicolumn{2}{|c|}{$\begin{array}{l}\text { Age Range } \\
\text { (Months) }\end{array}$}} & & \multicolumn{4}{|c|}{ Specimens Examined } \\
\hline & & & & \multicolumn{2}{|c|}{ Coeliacs } & \multicolumn{2}{|c|}{ Non-coeliacs } \\
\hline & & & & Serum & $\begin{array}{c}\text { Upper } \\
\text { Intestinal } \\
\text { Secretions }\end{array}$ & Serum & $\begin{array}{l}\text { Upper } \\
\text { Intestinal } \\
\text { Secretions }\end{array}$ \\
\hline $\begin{array}{c}0-5 \\
6-10 \\
11-15 \\
16-20 \\
21-30 \\
31-40 \\
41-50 \\
51-100 \\
>100\end{array}$ & $\begin{array}{l}\ldots \\
\cdots \\
\cdots \\
\because \\
\cdots \\
\cdots\end{array}$ & $\begin{array}{l}\cdots \\
\cdots \\
\cdots \\
\cdots \\
\cdots \\
\cdots\end{array}$ & $\begin{array}{l}\ldots \\
\ldots \\
\ldots \\
\ldots \\
\ldots \\
\ldots \\
\ldots\end{array}$ & $\begin{array}{l}0 \\
4 \\
5 \\
2 \\
3 \\
5 \\
4 \\
4 \\
6\end{array}$ & $\begin{array}{l}0 \\
3 \\
4 \\
2 \\
3 \\
5 \\
3 \\
4 \\
6\end{array}$ & $\begin{array}{r}4 \\
1 \\
1 \\
3 \\
11 \\
5 \\
1 \\
7 \\
5\end{array}$ & $\begin{array}{l}2 \\
0 \\
1 \\
3 \\
5 \\
4 \\
1 \\
4 \\
1\end{array}$ \\
\hline $\begin{array}{l}\text { Total } \\
\text { Males } \\
\text { Females }\end{array}$ & & $\begin{array}{l}\ldots \\
\cdots\end{array}$ & $\begin{array}{l}\ldots \\
\ldots\end{array}$ & $\begin{array}{l}33 \\
16 \\
17\end{array}$ & $\begin{array}{l}30 \\
16 \\
14\end{array}$ & $\begin{array}{l}38 \\
20 \\
18\end{array}$ & $\begin{array}{l}21 \\
11 \\
10\end{array}$ \\
\hline
\end{tabular}

TABLE II-Final Diagnoses for the 38 Children Who Did Not Have Coeliac Disease

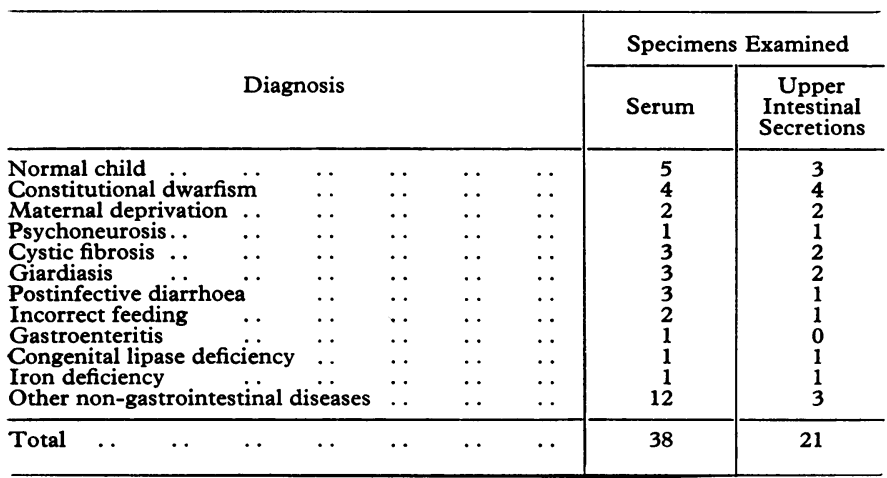

In these 71 children 0.5 to $1 \mathrm{ml}$ of serum was taken for immunological estimations when venepuncture was performed for diagnostic tests. Specimens of duodenojejunal fluid were obtained from 51 children who had small-bowel intubation for diagnostic tests (usually jejunal biopsy). Serum and secretion specimens were coded by number, frozen, and stored at $-20^{\circ} \mathrm{C}$.

Precipitin Tests.-Precipitating antibodies were detected by using Crowle's (1958) micro-gel-diffusion technique as modified by Heiner et al., (1962). This technique has been successfully used in a number of studies of dietary protein antibodies (Heiner et al., 1962; Holland et al., 1962; Beckwith and Heiner, 1966; Bayless et al., 1967). Immunodiffusion takes place in a 1-mm thick layer of agar on a microscope slide; $20-\mu l$ drops of antigen and antibody are placed in holes in a Perspex template lying on top of the agar. After two days' incubation the slides are washed and the precipitin lines stained with thiazine red. When dried, these slides can be mounted with coverslips, for permanent storage. Each coded specimen (serum or secretions) was tested in duplicate against the 10 antigens listed below. Results were read as positive or negative.

Cereal antigens: wheat flour (white), gluten (from British Drug Houses), oatmeal, rice flour, and cornflour. Aqueous extracts of these cereals were prepared as described by Heiner et al. (1962) using ice-cold phosphate-buffered saline at pH 7·2.

Animal protein antigens: Cow's milk, bovine calf serum, sheep serum, egg white, and egg yolk. Cow's milk was centrifuged to remove the fat and used neat and at 1/10 dilution in phosphate-buffered saline. Bovine calf serum and sheep serum were diluted $1 / 10$ in phosphate-buffered saline. Egg white and egg yolk were diluted $1 / 50$ in phosphate-buffered saline, centrifuged, and filtered.

\section{Results}

Precipitin lines were obtained with 9 of the 10 antigens used. Precipitins to cornflour were not detected. There was an exceptionally high incidence of precipitin lines when intestinal secretions were tested against sheep serum. This was due to an $\alpha$-globulin in the sheep serum reacting with trypsin in the secretions (Brown, 1971). These secretion/sheep serum results are therefore excluded from further consideration.

Tables III, IV, and V summarize the results of precipitin tests on the serum and intestinal secretions of the coeliac and non-coeliac children.

TABLE III-Precipitins to Cereal and Animal Proteins in Serum and Intestinal Secretions

\begin{tabular}{|c|c|c|c|c|}
\hline \multirow[b]{2}{*}{ Positive Precipitin Tests } & \multicolumn{2}{|c|}{ Coeliacs } & \multicolumn{2}{|c|}{ Non-coeliacs } \\
\hline & Serum & $\begin{array}{l}\text { Upper } \\
\text { Intestinal } \\
\text { Secretions }\end{array}$ & Serum & $\begin{array}{c}\text { Upper } \\
\text { Intestinal } \\
\text { Secretions }\end{array}$ \\
\hline $\begin{array}{l}\text { With cereal antigens only } \\
\text { With animal antigens only } \\
\text { With cereal and animal antigens } \\
\text { With none of the antigens used. }\end{array}$ & $\begin{array}{r}2 \\
6 \\
19 \\
6\end{array}$ & $\begin{array}{r}19 \\
3 \\
5 \\
3\end{array}$ & $\begin{array}{r}0 \\
3 \\
2 \\
33\end{array}$ & $\begin{array}{r}5 \\
2 \\
4 \\
10\end{array}$ \\
\hline Total No. of specimens examined & 33 & 30 & 38 & 21 \\
\hline
\end{tabular}

TABLE IV-Incidence of Precipitins to 10 Dietary Proteins in Serum and Intestinal Secretions of Coeliac and Non-coeliac Children

\begin{tabular}{|c|c|c|c|c|c|c|}
\hline \multirow[b]{2}{*}{ Antigen } & \multicolumn{3}{|c|}{ Serum } & \multicolumn{3}{|c|}{ Intestinal Secretions } \\
\hline & $\begin{array}{c}\text { Coeliacs } \\
\text { (33 } \\
\text { Cases) }\end{array}$ & $\begin{array}{c}\text { Non- } \\
\text { coeliacs } \\
(38 \\
\text { Cases) }\end{array}$ & $\mathbf{P}^{*}$ & $\begin{array}{c}\text { Coeliacs } \\
(30 \\
\text { Cases })\end{array}$ & $\begin{array}{c}\text { Non- } \\
\text { coeliacs } \\
(21 \\
\text { Cases })\end{array}$ & $\mathbf{P}^{*}$ \\
\hline $\begin{array}{l}\text { Wheat flour } \\
\text { Gluten } \quad . \\
\text { Oatmeal } \quad \text { R. } \\
\text { Rice flour } \\
\text { Cornflour }\end{array}$ & $\begin{array}{r}17 \\
16 \\
9 \\
4 \\
0 \\
15\end{array}$ & $\begin{array}{l}1 \\
1 \\
2 \\
0 \\
0 \\
3\end{array}$ & $\begin{aligned} & <0.01 \\
& <0.01 \\
0.02 & <\mathrm{P}<0.05 \\
\text { N.S. } & \\
\text { N.S. } & <0.01\end{aligned}$ & $\begin{array}{r}18 \\
18 \\
8 \\
0 \\
0 \\
2\end{array}$ & $\begin{array}{l}8 \\
4 \\
4 \\
0 \\
0 \\
0\end{array}$ & $\begin{array}{l}\text { N.S. } \\
<0.01 \\
\text { N.S. } \\
\text { N.S. } \\
\text { N.S. } \\
\text { N.S. }\end{array}$ \\
\hline $\begin{array}{l}\text { serum .. } \\
\text { Sheep serum } \\
\text { Egg white . . } \\
\text { Egg yolk .. }\end{array}$ & $\begin{array}{r}21 \\
17 \\
1 \\
6\end{array}$ & $\begin{array}{l}4 \\
2 \\
0 \\
0\end{array}$ & $\begin{aligned}<0.01 \\
<0.01 \\
\text { N.S. } \\
0.01<\text { P }<0.02\end{aligned}$ & $\begin{array}{l}1 \\
+ \\
2 \\
7\end{array}$ & $\begin{array}{l}1 \\
+ \\
2 \\
6\end{array}$ & $\begin{array}{l}\text { N.S. } \\
+ \\
\text { N.S. } \\
\text { N.S. }\end{array}$ \\
\hline
\end{tabular}

* $\chi^{2}$ test with Yates's correction applied.

十 Tests for precipitins to sheep serum in intestinal secretions were rendered invalid by the presence of trypsin/antitrypsin precipitin lines.

N.S. = Not significant.

TABLE v-Detection of Precipitins to 8 Dietary Proteins in Serum and Intestinal Secretions of 30 Coeliac Children

\begin{tabular}{|c|c|c|c|c|}
\hline \multirow[b]{2}{*}{ Antigen } & \multicolumn{4}{|c|}{ Precipitins Detected in: } \\
\hline & Serum only & $\begin{array}{l}\text { Intestinal } \\
\text { Secretions } \\
\text { Only }\end{array}$ & $\begin{array}{l}\text { Serum and } \\
\text { Intestinal } \\
\text { Secretions }\end{array}$ & $\begin{array}{l}\text { Neither Serum } \\
\text { nor Intestinal } \\
\text { Secretions }\end{array}$ \\
\hline $\begin{array}{ll}\text { Wheat flour } & \ldots \\
\text { Gluten } & \ldots \\
\text { Oatmeal .. } & \ldots \\
\text { Rice flour } & \ldots \\
\text { Cows' milk } & \ldots \\
\text { Bovine calf serum } \\
\text { Egg white } \\
\text { Egg yolk... }\end{array}$ & $\begin{array}{r}6 \\
3 \\
5 \\
4 \\
11 \\
19 \\
1 \\
5\end{array}$ & $\begin{array}{l}9 \\
8 \\
6 \\
0 \\
0 \\
1 \\
2 \\
7\end{array}$ & $\begin{array}{r}9 \\
10 \\
2 \\
0 \\
2 \\
0 \\
0 \\
0\end{array}$ & $\begin{array}{r}6 \\
9 \\
17 \\
26 \\
17 \\
10 \\
27 \\
18\end{array}$ \\
\hline
\end{tabular}

Intestinal Secretions.-Precipitins were detected in the upper intestinal secretions from 27 of the 30 coeliacs tested, but also from 11 of the 21 children who did not have coeliac disease. In the non-coeliac group the presence of precipitins was unrelated to age; positive tests were present in children aged 13-91 months. Most positive tests were with the antigens wheat flour, gluten, oats, and egg yolk. Only for gluten was the incidence significantly higher in coeliac secretions (Table IV). Precipitins to wheat flour or gluten were present in the intestinal secretions of 22 out of 30 coeliacs and of 8 out of 21 noncoeliacs.

Serum.-All but 6 of the 33 coeliac children had precipitins to cereal or animal antigens. For seven of the antigens studied 
the incidence of precipitins was significantly higher in coeliacs than in non-coeliacs. Of the 34 non-coeliacs aged more than 6 months, only two had serum precipitins (to cow's milk and bovine calf serum). In contrast, serum precipitins to several antigens were present in three of the four non-coeliacs aged less than 6 months. Two of these infants had cystic fibrosis and one had gastroenteritis.

Comparison of Precipitin Patterns in Serum and Intestinal Secretions.-Table V shows that although in 23 instances precipitins to a dietary antigen were detected in both serum and intestinal secretions, in 33 instances precipitins were detected only in the secretions and in 54 instances only in the serum.

Precipitins in the IgA-deficient Coeliac Patient.-One coeliac boy aged 13 months had IgA deficiency. In this child positive precipitin tests were as follows: serum-wheat flour, gluten, oatmeal, rice, cow's milk; intestinal secretions-wheat flour, gluten, bovine calf serum, and egg yolk.

\section{Discussion}

In their study of intestinal antibodies to wheat fractions in coeliac disease, Katz et al. (1968) found precipitins to a peptictryptic digest of gluten (fraction III) in the intestinal secretions of five out of eight untreated coeliacs, 2 out of 10 coeliac patients taking a gluten-free diet, and none of the 19 control subjects. We have examined the intestinal secretions of 51 children, hoping to confirm that secretion of antibodies to wheat or gluten is specific for coèliäc disease.

We used, as antigens, simple saline extracts of wheat flour and gluten, as these materials were readily available, easily prepared, and stored (an important fact if the technique was to be recommended as a screening method). Also, during the preliminary evaluation of the technique (using sera from adult coeliac patients) we were unable to detect precipitins when our preparations of gluten fraction III were used as antigens, whereas precipitins were readily detected with the simple saline extracts of cereals.

We have found that though precipitins to gluten or wheat flour extracts were present in the upper intestinal secretions of 22 out of 30 untreated coeliac children, these precipitins were also found in the secretions of 8 out of 21 non-coeliacs. The "non-coeliac" children were not representative of a normal childhood population, for most were undergoing investigation because of suspected gastrointestinal disease. However, the positive tests were not in undiagnosed coeliacs, for in all eight cases jejunal biopsy had been done and the histological appearance had been completely normal.

The differences between our results and those of Katz et al. (1968) in control subjects may be due to the different populations studied-their patients were mainly adults, ours are all children; they used a slightly different gel-diffusion technique and a different preparation of gluten as antigen. We have partly confirmed their work, in that we have found a significantly higher incidence of precipitins to gluten in the intestinal secretions of coeliac children when compared with non-coeliacs. This may be of fundamental aetiological significance in relation to coeliac disease, or it may simply be a reflection of increased immune responses to many dietary proteins in the coeliac children.

Intestinal secretions and stool extracts may contain antibodies to bacteria, viruses, and protozoa within the gut lumen (Berger et al., 1967; Girard and de Kalbermatten, 1970; Northrup and Hossain, 1970; Porter et al., 1970; Shaalan and Baker, 1970; Eddie et al., 1971). Antibodies to a variety of dietary proteins have also been detected in the stools of children with diarrhoea (Self et al., 1969; Davis et al., 1970). Thus it is not really surprising that we have found precipitins to cereal, bovine, and egg proteins in the intestinal secretions of these children, many, but not all, suffering from coeliac disease. However, we did not find that the presence of these precipitins was associated with clinical food intolerance, for the coeliac children who had precipitins to oats, milk, or egg all had satisfactory remissions when only wheat and rye were withdrawn.

Only four of the children studied were under 6 months of age; three of these infants had gastrointestinal disease and all three had serum precipitins to several dietary antigens. With such small numbers it is not possible to say if these precipitins were related to disease or to age. However, extensive studies have shown that nearly all artificially fed infants have serum antibodies to cow's milk (Gunther et al., 1960, 1962; Kletter et al., 1971), and today some infants are taking cereals and egg by the age of 6 weeks. Further studies of normal children are needed to find if there are always immune responses to newly introduced dietary proteins or if the presence of serum precipitins is an indication of disease.

An association between IgA deficiency and coeliac disease is recognized (Lancet, 1971). In IgA deficiency the serum contains antibodies to cows' milk, bovine, and sheep serum proteins (Buckley and Dees, 1969; Huntley et al., 1971), and we have confirmed that coeliac patients also have serum antibodies to these ruminant proteins. If there is permanent impairment of $\operatorname{IgA}$ responses in coeliac disease these antibodies to ruminant proteins might be expected to persist after treatment. This does not happen, for we have followed up coeliac children and have found that the incidence of precipitins falls sharply after treatment with a gluten-free diet (Carswell and Ferguson, unpublished). It seems likely that both in coeliac disease and IgA deficiency the presence of serum antibodies to food proteins is a result of increased absorption or persorption of an rigenic food protein molecules-for immunological reasons in IgA deficiency and as a result of small-bowel inflammation in untreated coeliac disease.

We are grateful to Professor J. H. Hutchison and Dr. R. A. Shanks, who allowed us to study patients under their care.

\section{References}

Alarcon-Segovia, D., Herskovic, T., Wakim, K. G., Green, P. A., and Scundamore, H.H (1964). American Fournal of Medicine, 36, 485 .

Bayless, T. M., Partin, J. S., and Partin, J. C. (1967). Bulletin of the fohns Hopkins Hospital, 120, 310.

Beckwith, A. C., and Heiner, D. C. (1966). Archives of Biochemistry and Biophysics, 117, 239.

Berger, R., Ainbender, E., Hodes, H. L., Zepp, H. D., and Hevizy, M. (1967). Nature, 214, 420

Booth, C. C. (1970a). British Medical fournal, 3, 725

Booth, C. C. (1970b). British Medical fournal, 4, 14

Brown, W. R. (1971). Fournal of Laboratory and Clinical Medicine, 77, 326. Buckley, R. H., and Dees, S. C. (1969). New England fournal of Medicine,

281, 465.
Crowle, A. J. (1958). Fournal of Laboratory and Clinical Medicine, 52, 784.

Crowle, A. J. (1958). Fournal of Laboratory and Clinical Medicine, 52, 784. (1970). New England fournal of Medicine, 282, 612.

Eddie, D. S., Schulkind, M. L., and Robbins, J. B. (1971). Fournal of Immunology, 106, 181 .

Girard, J. P., and de Kalbermatten, B. (1970). European fournal of Clinical Investigation, 1, 188.

Gunther, M., Aschaffenburg, R., Matthews, R. H., Parish, W. E., and Coombs, R. R. A. (1960). Immunology, 3, 296.

Gunther, M., Cheek, E., Matthews, R. H., and Coombs, R. R. A. (1962). International Archives of Allergy and Applied Immunology, 21, 257.

International Archives of Allergy and Applied Immuno
Heiner, D. C., et al. (1962). Fournal of Pediatrics, 61, 813.

Herskovic, T., Katz, J., Gryboski, J. D., and Spiro, H. M. (1968). Fournal of the American Medical Association, 203, 167.

Holland, N. H., Hong, R., Davis, N. C., and West, C. D. (1962). Fournal of Pediatrics, 61, 181 .

Huntley, C. C., Robbins, J. B., Lyerly, A. D., and Buckley, R. H. (1971). New England Fournal of Medicine, 284, 7.

Katz, J., Kantor, F. S., and Herskovic, T. (1968). Annals of Internal Medicine, 69, 1149.

Kenrick, K. G., and Walker-Smith, J. A. (1970). Gut, 11, 635.

Kletter, B., Gery, I., Freier, S., and Davies, A. M. (1971). International Archives of Allergy and Applied Immunology, 40, 656.

Lancet, 1971, 2, 144.

Northrup, R. S., and Hossain, S. A. (1970). Fournal of Infectious Diseases, 121,142 .

Porter, P., Noakes, D. E., and Allen, W. D. (1970). Immunology, 18, 909.

Rossipal, E. (1970). Lancet, 1, 251.

Rubin, C. E. Eidelman, S., and Weinstein, W. M. (1970). Gastroenterology, $58,409$.

Self, T. W. et al. (1969). Fournal of the American Medical Association, $207,2393$.

Shaalan, M., and Baker, R. P. (1970). American fournal of Clinical Pathology,

Taylor, K. B., Thomson, D. L., Truelove, S. C., and Wright, R. (1961) British Medical fournal, 2, 1727 